\title{
Historical analysis (1981-2017) of drought severity and magnitude over a predominantly arid region of Pakistan
}

\author{
Saadia Hina ${ }^{1,2,3, *}$, Farhan Saleem ${ }^{2,4}$ \\ ${ }^{1}$ State Key Laboratory of Numerical Modelling for Atmospheric Sciences and Geophysical Fluid Dynamics, \\ Institute of Atmospheric Physics, Chinese Academy of Sciences, Beijing 100029, PR China \\ ${ }^{2}$ College of Earth and Planetary Sciences, University of Chinese Academy of Sciences, Beijing 100049, PR China \\ ${ }^{3}$ Department of Environmental Sciences and Engineering, Government College University Faisalabad, Faisalabad 38000, \\ Pakistan \\ ${ }^{4}$ International Center for Climate and Environment Sciences, Institute of Atmospheric Physics, Chinese Academy of Sciences, \\ Beijing 100029, PR China
}

\begin{abstract}
Droughts are one of the multifaceted meteorological disasters affecting agriculture, livestock and water resources worldwide. Pakistan has a semiarid climate system with a high degree of interannual rainfall variability. This study evaluates the applicability and comparison of 3 drought indices (deciles index [DI], standardized precipitation index [SPI] and reconnaissance drought index [RDI]) in Pakistan. Monthly rainfall and temperature data (1981-2017) from 30 weather stations were used to analyze the current status of drought occurrence in terms of severity and magnitude. A nonparametric Mann-Kendall test and Sen's slope estimates were applied on drought indices to determine the statistical significance and magnitude of the trend. The DI captured the dry episodes in the region well, as Baluchistan and Sindh provinces have been seen to be more susceptible to droughts. The indices of SPI and RDI were well correlated at 3,6,9 and 12 mo timescales. Province-level analysis revealed the highest number of drought years during the 3 mo timescale and the lowest number of drought years during the 12 mo timescale. Overall, a linearly increasing trend of SPI and RDI (towards wetness) was observed, whereas the province-level analysis showed a statistically significant trend at the $95 \%$ confidence level for Khyber Pakhtunkhwa, Punjab and Sindh in the long-term drought analysis. Moreover, analyses of historical drought years and their intensity have been investigated and compared with a recent long drought episode (1999-2002). The analysis of historical drought events highlights the challenging nature of drought management in Pakistan. The outcomes of this study would help water resource managers to investigate drought response measures for drought preparedness in the country.
\end{abstract}

KEY WORDS: Drought indices $\cdot$ Severity $\cdot$ Trend analysis $\cdot$ Climate change $\cdot$ Pakistan

\section{INTRODUCTION}

Drought is one of the most damaging hydrometeorological hazards that are recurrent in nature (Mishra \& Singh 2010, Guha-Sapir et al. 2012, Samaniego et al. 2013). An increase in the severity and magnitude of drought episodes due to warming has been re-

\footnotetext{
${ }^{*}$ Corresponding author: saadiahina@yahoo.com
}

ported worldwide (Gocic \& Trajkovic 2014, Duffy et al. 2015, Zhao \& Dai 2015, Hui-Mean et al. 2018). Droughts are directly linked to water availability, so any shift in drought characteristics due to a warming climate would affect water demand and food security (Nam et al. 2015, Touma et al. 2015). The phenomenon of drought mostly persists over arid to semiarid

() The authors 2019. Open Access under Creative Commons by Attribution Licence. Use, distribution and reproduction are unrestricted. Authors and original publication must be credited. 
environments where economies are strongly dependent on agriculture (Kazmi et al. 2015, Ahmed et al. 2018a). Interannual rainfall variability makes an arid region more susceptible to drought because of below-average rainfall (Adnan et al. 2017). Such prolonged drought conditions may in turn cause severe desertification, increased frequency of aerosol loading and more intense dust storm events affecting human health, ecosystems and regional climate, as observed in Southwest Asia (Kaskaoutis et al. 2012, Rashki et al. 2012, 2013a,b, 2015, 2017). The timely information obtained through various drought indices about the start and areal extent of droughts is beneficial for making appropriate contingency plans (Morid et al. 2006).

Some studies on drought assessment focus on a single index (Du et al. 2013, Gocic \& Trajkovic 2014, Adnan et al. 2015). Climatic conditions vary regionally in the world; thus, to have a complete picture of drought including its spatiotemporal extent and severity, it is effective to calculate and use various drought indices for drought assessment and monitoring (Mendicino et al. 2008). To quantify droughts, many studies have been carried out in different regions of the world, and almost 50 indices have been developed based on different variables. Despite the high number of drought indices available, most provide only a general description of droughts with no information about drought risk related to pre- and post-drought episodes (Kim et al. 2011, Huang et al. 2015, Li et al. 2015, Ahmed et al. 2016).

Various meteorological organizations generally use some of the well-known indicators to monitor droughts worldwide such as the standardized precipitation index (SPI), standardized precipitation evapotranspiration index and Palmer drought severity index in the USA (Palmer 1968, McKee et al. 1993); reconnaissance drought index (RDI) in Europe; deciles index (DI) in Australia (Gibbs \& Maher 1967); and China $Z$ index in China (Wu et al. 2001) as endorsed by the World Meteorological Organization (Hayes et al. 2011, Svoboda et al. 2012).

Pakistan is predominantly categorized as an arid country (low precipitation and high temperatures) with an agricultural-based economy (Adnan et al. 2015 , 2017). According to the land utilization survey, 34.15 Mha of land area is agricultural, while 23.60 Mha of land area is uncultivable; $25 \%$ of the cultivated land is rainfed, which plays a vital role in the country's economy (Adnan \& Khan 2009, Kazmi et al. 2015). The economy's heavy reliance on agriculture has made Pakistan more susceptible to drought risks. Many studies in Pakistan have focused on drought characterization (Xie et al. 2013, Ahmed et al. 2016, Haroon et al. 2016, Adnan et al. 2018). In recent decades, climate change has severely affected socioeconomic and environmental conditions in Pakistan and surrounding areas of Southwest Asia (Abbas et al. 2018a,b).

The current study is designed to monitor droughtprone areas of Pakistan. This paper identifies and compares the severity and magnitude of drought in different provinces of Pakistan by calculating drought indices (DI, SPI and RDI) at 3, 6, 9 and 12 mo timescales. The time series analysis of SPI and RDI helps to determine historical drought episodes. This study will help policy makers to formulate contingency plans for climate change-induced droughtprone areas in the region.

\section{MATERIALS AND METHODS}

\subsection{Study area}

Pakistan is a predominantly arid region lying within the geographic coordinates of $23.38^{\circ}-30.25^{\circ} \mathrm{N}$ latitude and $61.78^{\circ}-74.30^{\circ} \mathrm{E}$ longitude, with a total land area of $796096 \mathrm{~km}^{2}$. Fig. 1 shows weather stations spatially distributed in different provinces of Pakistan as well as Pakistan's borders with China to the north, the Arabian Sea to the south, India to the east and Iran and Afghanistan to the west. Agricultural practices contribute $25 \%$ of the total gross domestic product of Pakistan, whereas the projected cultivated land area percentage is about $27.87 \%$. Based on its geography, there is great variability in

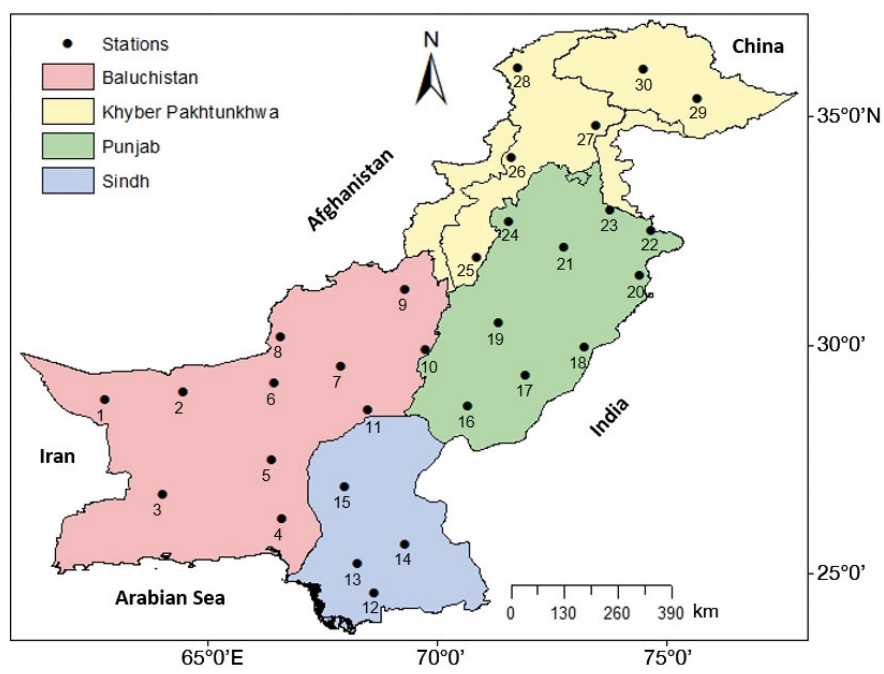

Fig. 1. Study area, showing provinces and weather stations in Pakistan 
Table 1. Weather stations in Pakistan

\begin{tabular}{|c|c|c|c|c|}
\hline $\begin{array}{l}\text { Station } \\
\text { no. }\end{array}$ & $\begin{array}{c}\text { Station } \\
\text { name }\end{array}$ & $\begin{array}{l}\text { Elevation } \\
\text { (MSL) }\end{array}$ & $\begin{array}{c}\text { Latitude } \\
\left({ }^{\circ} \mathrm{N}\right)\end{array}$ & $\begin{array}{c}\text { Longitude } \\
\left({ }^{\circ} \mathrm{E}\right)\end{array}$ \\
\hline 1 & Nokkundi & 682 & 28.81 & 62.76 \\
\hline 2 & Dalbadin & 848 & 28.98 & 64.46 \\
\hline 3 & Panjgur & 968 & 26.75 & 64.00 \\
\hline 4 & Lasbella & 87 & 26.23 & 66.62 \\
\hline 5 & Khuzdar & 1231 & 27.50 & 66.38 \\
\hline 6 & Kalat & 2015 & 29.17 & 66.44 \\
\hline 7 & Sibbi & 133 & 29.55 & 67.88 \\
\hline 8 & Quetta & 1626 & 30.2 & 66.58 \\
\hline 9 & Zhob & 1405 & 31.21 & 69.28 \\
\hline 10 & Barkhan & 1097 & 29.92 & 69.74 \\
\hline 11 & Jacobabad & 55 & 28.59 & 68.47 \\
\hline 12 & Badin & 09 & 24.61 & 68.62 \\
\hline 13 & Hyderabad & 28 & 25.23 & 68.25 \\
\hline 14 & Chhor & 05 & 25.67 & 69.30 \\
\hline 15 & Padidan & 46 & 26.91 & 67.98 \\
\hline 16 & Khanpur & 88 & 28.67 & 70.66 \\
\hline 17 & Bahawalpur & 110 & 29.35 & 71.93 \\
\hline 18 & Bahawalnagar & Ir $\quad 161$ & 29.96 & 73.21 \\
\hline 19 & Multan & 122 & 30.49 & 71.33 \\
\hline 20 & Lahore & 214 & 31.52 & 74.40 \\
\hline 21 & Sargodha & 187 & 32.14 & 72.76 \\
\hline 22 & Sialkot & 255 & 32.52 & 74.65 \\
\hline 23 & Jhelum & 287 & 32.96 & 73.76 \\
\hline 24 & Mianwali & 210 & 32.71 & 71.55 \\
\hline 25 & D.I.Khan & 171 & 31.93 & 70.85 \\
\hline 26 & Peshawar & 327 & 34.11 & 71.61 \\
\hline 27 & Balakot & 995 & 34.79 & 73.45 \\
\hline 28 & Chitral & 1498 & 36.06 & 71.74 \\
\hline 29 & Sakardu & 2317 & 35.39 & 75.66 \\
\hline 30 & Gilgit & 1460 & 36.02 & 74.49 \\
\hline
\end{tabular}

the climate of Pakistan. Annual mean temperatures during winter and summer range between 12-20 and $19-35^{\circ} \mathrm{C}$, respectively. Annual average precipitation ranges between 30 and $400 \mathrm{~mm}$ from south to north with a maximum gradient of 900-1800 $\mathrm{mm}$ in submountainous areas (Adnan \& Khan 2009). This interannual rainfall variability makes the arid region (covering $75 \%$ land area of Pakistan) more susceptible to drought risks. purpose, monthly rainfall ( $\mathrm{mm}$ ) and maximum and minimum temperature $\left({ }^{\circ} \mathrm{C}\right)$ data covering the historical period of $37 \mathrm{yr}$ (1981-2017) were obtained from the Pakistan Meteorological Department. A list of weather stations along with their latitudes and longitudes is presented in Table 1. Three drought indices (DI, SPI and RDI) were calculated using monthly climate data of 30 weather stations spatially distributed at the province level in the region.

\subsection{Drought indices}

To have a clear idea about the severity and magnitude of drought episodes in the region, 3 types of drought-related indices were used: DI, SPI and RDI. A brief description of the indices follows.

\subsubsection{DI}

One of the simplest drought index calculation methods is DI. According to this method, long-term monthly rainfall data of an extended length are ranked in descending order to make a cumulative frequency distribution (Gibbs \& Maher 1967). Tigkas et al. (2015) grouped DI into 5 classes, shown in Table 2.

\subsubsection{SPI}

SPI is widely used to calculate rainfall deficit in an area of interest during a certain period of time (McKee et al. 1993). SPI can be calculated for a range of timescales including monthly, quarterly, biannually and annually. Mishra \& Singh (2010) investigated the versatility of SPI in both short-term (soil moisture) and long-term (stream flow) water resource management. SPI well distinguished the dry and wet years (Soro et al. 2014).

\subsection{Data collection}

The present study sought to investigate the drought-prone areas in different provinces of Pakistan. However, a major problem in hydroclimate investigations is the lack of long-term records and reliable observations in many parts of the globe (Ahmed et al. 2018a). For this
Table 2. Classes of drought indices. DI: deciles index; SPI: standardized precipitation index; RDI: reconnaissance drought index

\begin{tabular}{|c|c|c|c|}
\hline DI class & DI value & SPI and RDI class & $\begin{array}{l}\text { SPI and } \\
\text { RDI value }\end{array}$ \\
\hline & & Extremely wet & $\geq 2.0$ \\
\hline Much above normal & 9-10 (highest 20\%) & Severely wet & 1.50 to 1.99 \\
\hline Above normal & $7-8$ (next highest $20 \%$ ) & Moderately wet & 1.00 to 1.49 \\
\hline Near normal & 5-6 (middle $20 \%$ ) & Near normal & -0.99 to 0.99 \\
\hline Below normal & 3-4 (next lowest $20 \%$ ) & Moderate drought & -1.00 to -1.49 \\
\hline \multirow[t]{2}{*}{ Much below normal } & $1-2$ (lowest $20 \%$ ) & Severe drought & -1.50 to -1.99 \\
\hline & & Extreme drought & $\leq-2.00$ \\
\hline
\end{tabular}


To compute SPI, a long-term precipitation record is first fitted to a probability distribution (e.g. gamma distribution) that is then further transformed into a normal distribution so that the mean SPI is zero (McKee et al. 1995, Edwards 1997). It is expressed mathematically as:

$$
\mathrm{SPI}=\frac{\left(X_{i j}-\bar{X}\right)}{\sigma}
$$

where $X$ is seasonal precipitation at the $i$ th rain gauge and $j$ th observation, $\bar{X}$ is the long-term seasonal mean and $\sigma$ is the standard deviation. Droughts are classified according to the SPI values (Table 2).

\subsubsection{RDI}

RDI is a meteorological index for the assessment of droughts and classified in terms of its initial value $\left(\alpha_{k}\right)$, normalized value $\left(\mathrm{RDI}_{\mathrm{n}}\right)$ and standardized value $\left(\mathrm{RDI}_{\mathrm{st}}\right)$ (Tsakiris \& Vangelis 2005, Tsakiris et al. 2007). It provides a realistic representation of drought conditions, as it integrates precipitation along with potential evapotranspiration (PET), and can also be used to assess drought conditions in areas with diverse climatic characteristics. Because of its uniqueness, the RDI is universally applicable compared to other drought-related indices (Thomas et al. 2016). There are various methods to calculate PET; however, some of these methods are data demanding.

It is reported that temperature-based methods to calculate PET for the RDI estimation present adequate results (Vangelis et al. 2013). Hence, PET was calculated with the temperature-based method given by Thornthwaite (1948). For this method, a mean temperature data set is required. In addition, the number of years, starting year and latitude of the study area should also be defined (Tigkas et al. 2015). The latitude is used to adjust the number of sunlight hours over the course of the year.

To calculate PET using the Thornthwaite method, first the monthly Thornthwaite heat index (i) is calculated, using the formula:

$$
i=\left(\frac{t}{5}\right)^{1.514}
$$

where $t$ is the mean monthly temperature.

The annual heat index $(I)$ is calculated as the sum of $i$ :

$$
I=\sum_{i=1}^{12} i
$$

Thornthwaite reported a PET equation based on monthly meteorological data as:

$$
\mathrm{PET}=16.0 \times\left(\frac{10 \times t}{I}\right)^{A}
$$

where $t$ is the monthly average temperature, $I$ is the annual heat index and $A$ is a constant.

After PET calculation, the $\alpha_{k}$ of RDI is calculated for the $i^{\text {th }}$ year in a time basis of $k$ (months) using the following equation:

$$
\alpha_{k}^{(i)}=\frac{\sum_{j=1}^{k} P_{i j}}{\sum_{j=1}^{k} \mathrm{PET}_{i j}}
$$

where $P_{i j}$ and $\mathrm{PET}_{i j}$ are the precipitation and the PET of month $j$ of year $i$ and $N$ is the total number of years of the available data.

The initial formulation of $\mathrm{RDI}_{\text {st }}$ (Tsakiris \& Vangelis 2005) used the assumption that $\alpha_{k}$ values follow the lognormal distribution and $\mathrm{RDI}_{\mathrm{st}}$ is calculated as:

$$
\mathrm{RDI}_{\mathrm{st}}^{(i)}=\frac{y^{(i)}-\bar{y}}{\hat{\sigma}_{y}}
$$

where $y^{(i)}$ is the $\ln \left(\alpha_{k}^{(i)}\right), \bar{y}$ is its arithmetic mean and $\hat{\sigma}_{y}$ is its standard deviation. Positive values of $\mathrm{RDI}_{\mathrm{st}}$ indicate wet periods, while negative values indicate dry periods in the defined area (Tigkas et al. 2013). The RDI is classified in a similar way as SPI (Table 2).

\subsection{Statistical tests}

Trend analysis of annual to interannual time series of drought indices was performed using the non-parametric Mann-Kendall test (Mann 1945, Kendall 1948) and Sen's slope (Sen 1968) estimates during the historical period of 1981-2017 (Table 3). The Mann-Kendall test estimates the trend significance, and the Sen's method calculates the magnitude of an existing trend. Trend analysis was performed using the Excel template application MAKESENS (Salmi et al. 2002), which uses 2 different approaches to test for trends in a given time series based on the number of observations. If the number of observations is less than 10, MAKESENS uses the $S$ statistic (Gilbert 1987); otherwise, it uses the $Z$ statistic (normal distribution). Many studies around the world have used these statistical tests to monitor trends in long-term hydroclimatological investigations (Zhang et al. 2010, 2015, Mondal et al. 2012, Tabari et al. 2012, Du et al. 2013, Hanif et al. 2013, Gocic \& Trajkovic 2014, Abbas et al. $2018 \mathrm{a}, \mathrm{b})$. Table 3 shows the $Z$ values of the MannKendall test for trends in drought indices. Values greater than 1.97 or less than -1.97 indicate a significant trend (95\% confidence level). 
Table 3. Values of Mann-Kendall $(Z)$ test and Sen's slope $(Q)$ estimates for drought indices during the historical period of 1981-2017. SPI: standardized precipitation index; RDI: reconnaissance drought index; KPK: Khyber Pakhtunkhwa. Bold: significant at 95\% level ( $p<0.05$ )

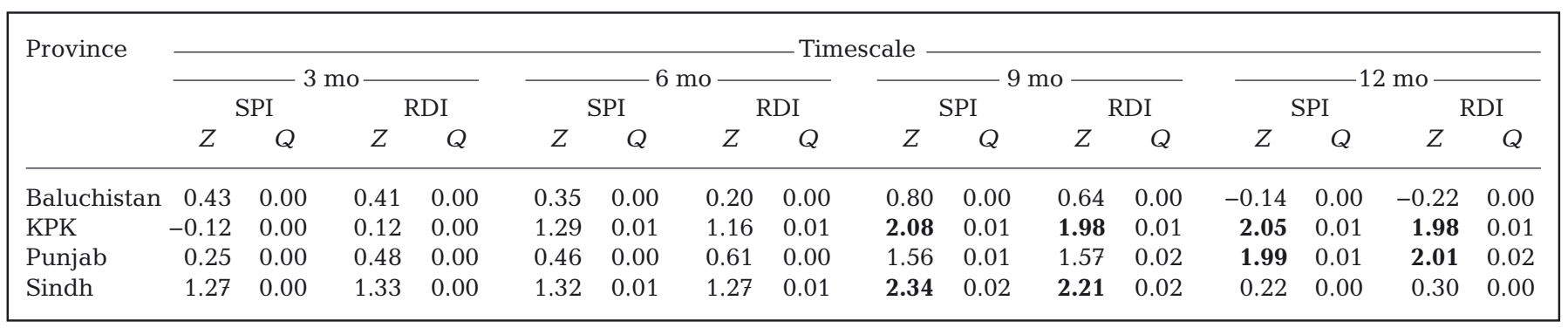

\section{RESULTS}

In Pakistan, high-latitude northern areas receive more rainfall compared to low-latitude southern areas (Adnan \& Khan 2009, Hanif et al. 2013). In the north, the high amount of annual average rainfall is associated with 2 seasonal phenomena, western disturbances and summer monsoons, that occur in winter and summer, respectively (Adnan etal. 2015). These phenomena are also responsible for seasonal rainfall in the southern areas of Pakistan. However, the lower amount of rainfall makes the southern side more susceptible to droughts (Adnan et al. 2018).

\subsection{Indices analysis}

Different drought indices have different features and calculation methods and require different data sets that may be appropriate for some regions while inappropriate for others. In this manuscript, the historical (1981-2017) analysis of drought indices (DI, SPI, RDI) was performed to examine the occurrence of droughts in terms of their severity and magnitude. The comparative analysis of SPI and RDI affirmed that RDI is good enough to capture drought episodes in the region. For better understanding, the above-mentioned indices were further compared provincially for the study area at 3,6,9 and 12 mo timescales.

\subsubsection{DI}

This index identifies wet and dry years by distributing long-term monthly rainfall data into its $10 \%$ parts
(Gibbs \& Maher 1967). It helps to evaluate the percentage rainfall departure in dry periods. During the analysis period (1981-2017), 37 years were classified as wet and dry years by distributing rainfall into the classes of much above normal rainfall to the years of much below normal rainfall (Table 2). In total, 14 years depict higher values than mean annual rainfall ( 1 of which is classified as much above normal), and 11 years depict lower values (3 of which are classified as much below normal) based on the decadal analysis (Table 4). The DI was found to be very responsive to rainfall events of a particular year, but it has incon-

Table 4. Per-decade analysis of dry and wet years according to deciles index method. n: number of events within time period; KPK: Khyber Pakhtunkhwa

\begin{tabular}{|c|c|c|c|c|c|c|c|c|c|c|}
\hline \multirow[t]{2}{*}{ Time period } & \multicolumn{2}{|c|}{$\begin{array}{c}\text { Much below } \\
\text { normal }\end{array}$} & \multicolumn{2}{|c|}{$\begin{array}{c}\text { Below } \\
\text { normal }\end{array}$} & \multicolumn{2}{|c|}{$\begin{array}{l}\text { Near } \\
\text { normal }\end{array}$} & \multicolumn{2}{|c|}{$\begin{array}{l}\text { Above } \\
\text { normal }\end{array}$} & \multicolumn{2}{|c|}{$\begin{array}{c}\text { Much above } \\
\text { normal }\end{array}$} \\
\hline & $\mathrm{n}$ & $\%$ & $\mathrm{n}$ & $\%$ & $\mathrm{n}$ & $\%$ & $\mathrm{n}$ & $\%$ & $\mathrm{n}$ & $\%$ \\
\hline \multicolumn{11}{|l|}{ Baluchistan } \\
\hline $1981 / 82-1990 / 91$ & 0 & 0 & 2 & 20 & 5 & 50 & 3 & 30 & 0 & 0 \\
\hline $1991 / 92-2000 / 01$ & 2 & 20 & 3 & 30 & 1 & 10 & 3 & 30 & 1 & 10 \\
\hline $2001 / 02-2010 / 11$ & 2 & 20 & 2 & 20 & 4 & 40 & 1 & 10 & 1 & 10 \\
\hline $2011 / 12-2017 / 18$ & 0 & 0 & 2 & 20 & 3 & 30 & 2 & 20 & 0 & 0 \\
\hline \multicolumn{11}{|l|}{ KPK } \\
\hline 1981/82-1990/91 & 1 & 10 & 3 & 30 & 5 & 50 & 1 & 10 & 0 & 0 \\
\hline $1991 / 92-2000 / 01$ & 0 & 0 & 2 & 20 & 6 & 60 & 2 & 20 & 0 & 0 \\
\hline $2001 / 02-2010 / 11$ & 0 & 0 & 3 & 30 & 1 & 10 & 4 & 40 & 2 & 20 \\
\hline $2011 / 12-2017 / 18$ & 0 & 0 & 2 & 20 & 4 & 40 & 1 & 10 & 0 & 0 \\
\hline \multicolumn{11}{|l|}{ Punjab } \\
\hline $1981 / 82-1990 / 91$ & 1 & 10 & 2 & 20 & 5 & 50 & 2 & 20 & 0 & 0 \\
\hline 1991/92-2000/01 & 0 & 0 & 3 & 30 & 2 & 20 & 4 & 40 & 1 & 10 \\
\hline $2001 / 02-2010 / 11$ & 1 & 10 & 2 & 20 & 1 & 10 & 6 & 60 & 0 & 0 \\
\hline $2011 / 12-2017 / 18$ & 0 & 0 & 0 & 0 & 1 & 10 & 6 & 60 & 0 & 0 \\
\hline \multicolumn{11}{|l|}{ Sindh } \\
\hline 1981/82-1990/91 & 1 & 10 & 2 & 20 & 5 & 50 & 2 & 20 & 0 & 0 \\
\hline $1991 / 92-2000 / 01$ & 1 & 10 & 3 & 30 & 2 & 20 & 4 & 40 & 0 & 0 \\
\hline $2001 / 02-2010 / 11$ & 1 & 10 & 2 & 20 & 2 & 20 & 4 & 40 & 1 & 10 \\
\hline 2011/12-2017/18 & 0 & 0 & 1 & 10 & 3 & 30 & 3 & 30 & 0 & 0 \\
\hline \multicolumn{11}{|l|}{ Pakistan } \\
\hline 1981/82-1990/91 & 1 & 10 & 2 & 20 & 5 & 50 & 2 & 20 & 0 & 0 \\
\hline $1991 / 92-2000 / 01$ & 1 & 10 & 3 & 30 & 2 & 20 & 4 & 40 & 0 & 0 \\
\hline $2001 / 02-2010 / 11$ & 1 & 10 & 2 & 20 & 2 & 20 & 4 & 40 & 1 & 10 \\
\hline $2011 / 12-2017 / 18$ & 0 & 0 & 1 & 10 & 3 & 30 & 3 & 30 & 0 & 0 \\
\hline
\end{tabular}


sistent spatiotemporal variability (Morid et al. 2006). The phenomena of western disturbances and summer monsoons are responsible for the interannual rainfall variability over the Indian subcontinent (Hunt et al. 2018). However, many studies reported changes in the per-decade trend of annual rainfall in Pakistan (Salma et al. 2012, Ahmed et al. 2016, 2018a, Adnan et al. 2017). The province-level analysis revealed that Baluchistan experiences the maximum number of years with much below normal rainfall followed by Sindh, Punjab and Khyber Pakhtunkhwa (KPK) (Table 4). Therefore, a higher degree of drought vulnerability is seen for Baluchistan and Sindh provinces (Zhang et al. 2012). Regional analysis revealed a dominance of dry years during the first 2 decades, while the last 2 decades revealed a dominance of wet years (Table 4 ).

\subsubsection{SPI and RDI}

SPI and RDI were analyzed and compared together because of the same drought classes (Table 2). SPI requires only precipitation data, while RDI considers both precipitation and PET data to capture drought episodes in the region of interest (Tigkas et al. 2013, 2015). Historical drought episodes negatively impact water resources worldwide (Trnka et al. 2016). The scatter plot of SPI and RDI revealed that the difference between both indicators increases with an increase in timescale (Zarch et al. 2011). It is evident that the climate trend is gradually shifting from a drier to a wetter period (Adnan \& Khan 2009). The temporal analysis of SPI and RDI with the coefficient of determination $\left(R^{2}\right)$ was performed at different timescales, and both of the indices are well correlated at $3 \mathrm{mo}\left(\mathrm{R}^{2}=0.987\right)$, $6 \mathrm{mo}\left(\mathrm{R}^{2}=0.993\right), 9 \mathrm{mo}\left(\mathrm{R}^{2}=0.992\right)$ and 12 mo $\left(\mathrm{R}^{2}=0.985\right)$ timescales (Fig. 2). However, the RDI-calculated wet and dry periods were found to be larger in magnitude than the SPI-calculated wet and dry periods.

\subsection{Province-level analysis}

The comparative analysis of SPI and RDI was performed at the province level on a 3, 6, 9 and 12 mo basis to monitor the drought vulnerability in each province. A significant trend was observed in the provinces of KPK, Punjab and Sindh on a 9 and 12 mo timeframe (Table 3 ). From the results, it is evident that most of the provinces show non-significant trends for selected indices at all the timescales except KPK (3 mo) and Baluchistan (9 mo) (Table 3), perhaps due to the relatively short phase of data in the analysis period or the interannual rainfall variability (Aguilar et al. 2005). However, the aggregated time series are presented and discussed to highlight several features that represent the hydroclimatological changes in the study area.

\subsubsection{Three month analysis}

Short-term droughts are represented by the 3 mo timescale and derive from SPI and RDI monthly values. Tsakiris et al. (2007) further classified this timescale as moderate drought $(-1.0$ to -1.49$)$, severe drought ( -1.50 to -1.99$)$ and extreme drought $(-2.0$ or less), and Tigkas (2008) reported that it would negatively affect the growing season length of agricultural crops. Short-term analysis of SPI and RDI shows that

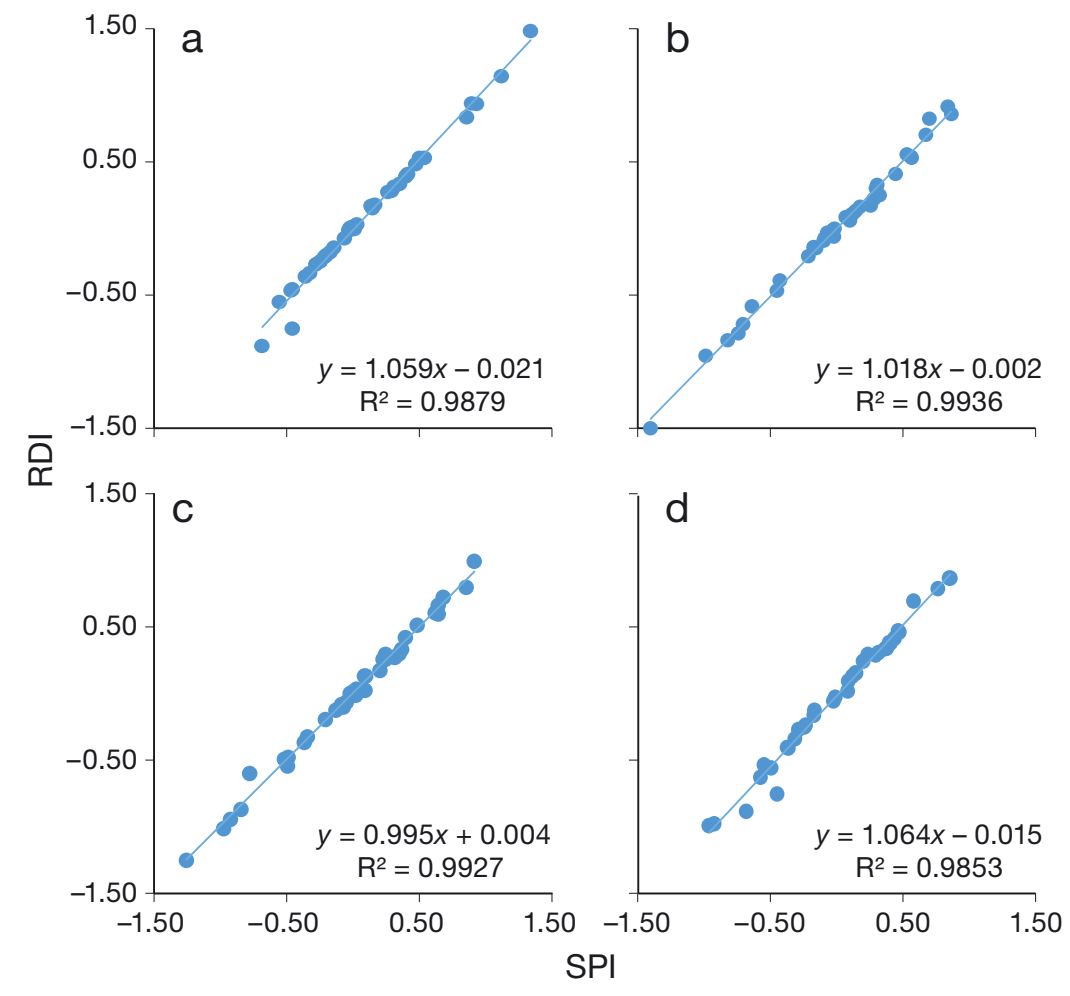

Fig. 2. Comparative analysis of SPI and RDI at (a) 3, (b) 6, (c) 9 and (d) $12 \mathrm{mo}$ timescales during the historical period of 1981-2017. SPI: standardized precipitation index; RDI: reconnaissance drought index 
KPK (northern areas) experienced the most (16 years) and Sindh experienced the least (4 years) number of moderate droughts during the analysis period (Fig. 3b,d). The results of this short-term drought analysis are in good agreement with a study conducted in Bangladesh, where the northwestern side of the country was found to be more vulnerable to droughts compared to the southwestern side (Mondol et al. 2016). The maximum length of moderate droughts for northern areas was recorded during 1998-2002, and in Sindh, it was recorded during 1986-1988. Adnan et al. (2015) also reported this period of droughts in
Sindh, Pakistan. The southern areas of Pakistan are highly dependent on monsoon rainfall, and the seasonal rainfall deficit would lead to drought conditions in the region. In the province of Punjab, 12 years of moderate droughts were investigated, with a strong duration during the 2 periods of 1986-1987 and 19992001 (Fig. 3c). It is evident that climatic extremes had triggered the dry spells in semiarid Punjab, Pakistan (Farhat et al. 2013). Baluchistan was the only province experiencing a severe drought episode in 1992 at the 3 mo timescale. In total, 12 years of moderate droughts were found having a maximum intensity during 1987-
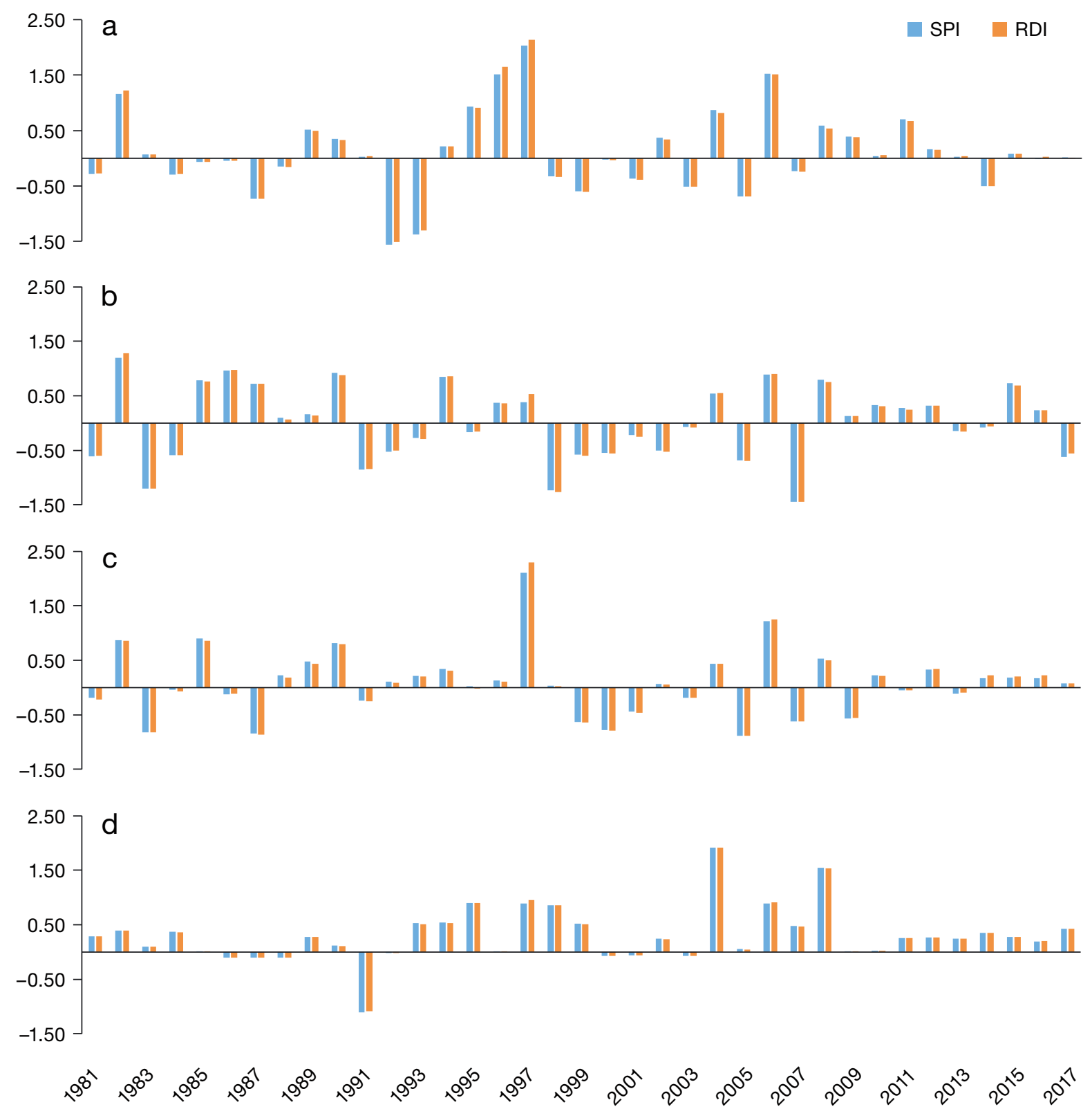

Fig. 3. Annual time series analysis of SPI and RDI at a 3 mo timescale for (a) Baluchistan, (b) Khyber Pakhtunkhwa, (c) Punjab and (d) Sindh provinces of Pakistan 
1988, 1992-1993 and 1998-1999 (Fig. 3a). The upper northeastern part of Baluchistan was found to be more vulnerable to droughts, as it receives a low amount of rain during the winter and summer seasons (Ahmed et al. 2016). The 3 mo analysis of both indices investigated the total number of drought (moderate to severe) months in Baluchistan (39 for SPI and 39 for RDI), northern areas (48 for SPI and 48 for RDI), Punjab (39 for SPI and 36 for RDI) and Sindh (12 for SPI and 12 for RDI) (Table 4). This short-term (3 mo) drought period significantly affected the developmental stages of winter season crops in Pakistan (Ahmed et al. 2018b).

\subsubsection{Six month analysis}

The 6 mo drought analysis period is specifically important for rainfed agricultural crops (Tigkas 2008). Comparison of SPI and RDI at the 6 mo timescale revealed that all provinces in the region experienced the recent drought-intensive episode of 2000-2002 (Fig. 4). During the 20th century, the same period of drought episode was identified in Southwest Asia (Malik et al. 2013) and southeastern Iran resulted in increased dust loading and intense dust storms (Rashki et al. 2013a,b,c). Atmospheric circulation patterns, particularly La Niña, played a significant role in

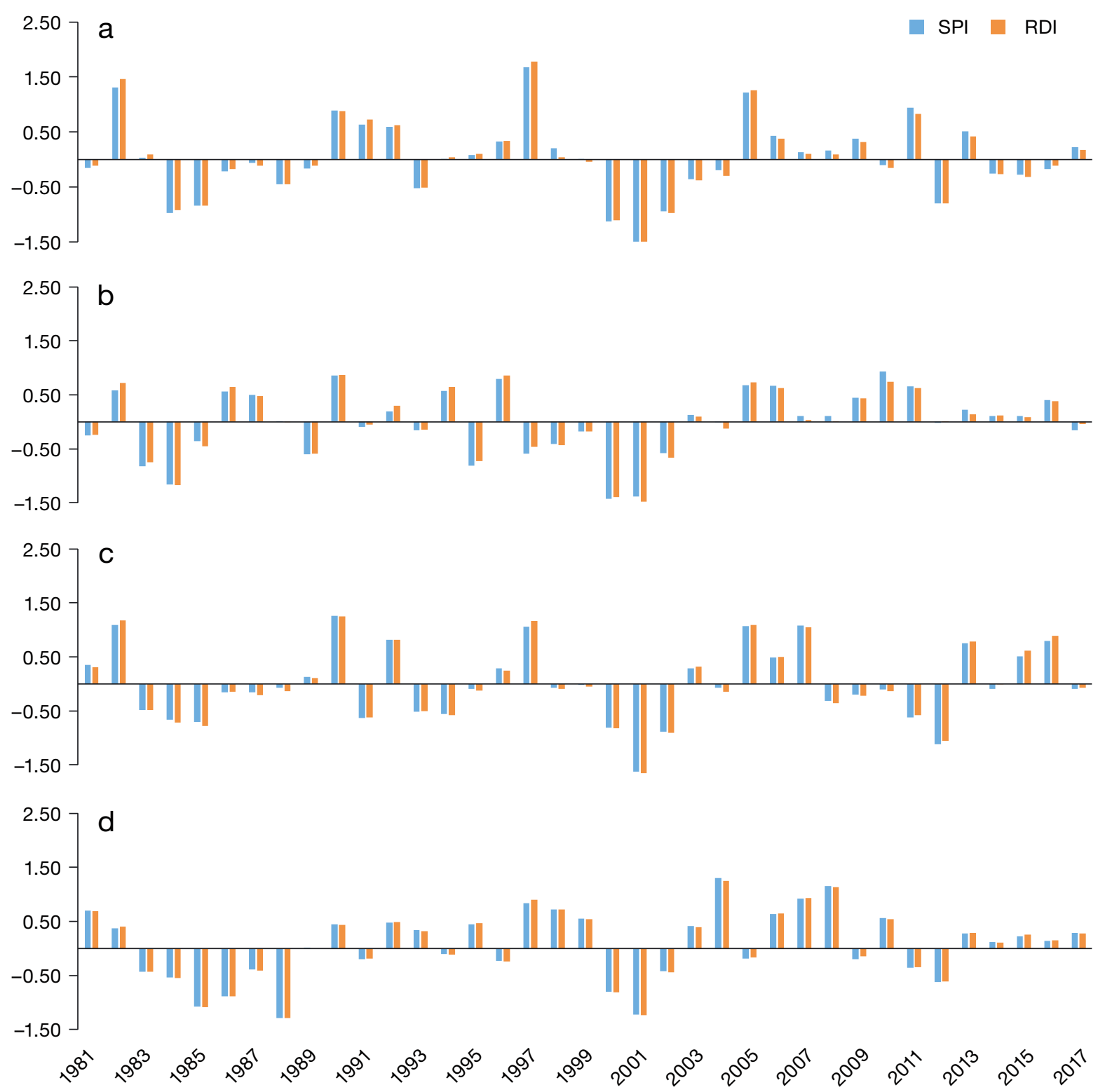

Fig. 4. Annual time series analysis of SPI and RDI at a 6 mo timescale for (a) Baluchistan, (b) Khyber Pakhtunkhwa, (c) Punjab and (d) Sindh provinces of Pakistan 
causing droughts in the Middle East and Southwest Asia (Barlow et al. 2016). Province-level analysis of both indices showed that northern areas (Fig. 4b) face the highest number of moderate droughts (in terms of magnitude) followed by Sindh (Fig. 4d), Baluchistan (Fig. 4a) and Punjab (Fig. 4c), evidencing the weak drought episodes in mid-2009 and 2010 over Pakistan (Anjum et al. 2010, 2012). The main reason behind this period of weak droughts was the development of the El Niño drought year, which caused $30 \%$ below-normal rainfall in the region during the monsoon season. Table 5 shows the number of moderate to severe drought months $(12,18,12$ and 18) for Baluchistan, northern areas, Punjab and Sindh, respectively, calculated using SPI and RDI. The results clearly show that the newly developed index of RDI also performs well with SPI in identifying drought episodes at different timescales (Tigkas et al. 2017).

\subsubsection{Nine month analysis}

Analyses of SPI and RDI at 9 and 12 mo timescales represent long-term droughts (Haied et al. 2017). According to Fig. 5, Baluchistan (Fig. 5a) experienced 3 consecutive years of moderate droughts from 2000 to 2002, whereas northern areas (Fig. 5b) experienced only 1 yr of drought, but it was severe in intensity (2000). The province of Punjab (Fig. 5c) revealed 5 years (1984, 1993, 2000, 2002 and 2012) of moderate droughts. In Sindh (Fig. 5d), Pakistan, 3 years (1986, 1988 and 2000) of drought episodes, of moderate to severe intensity, were investigated. Anomalous and prolonged drought conditions caused by a large deficit in monsoon rainfall in 2002 were also observed in South Asia, especially over India, and resulted in increased aerosol loading (Kaskaoutis et al. 2012).
Water deficit and recurrent drought spells in the region of central Southwest Asia badly affected socioeconomic conditions (Oki \& Kanae 2006, Kaniewski et al. 2012), whereas the drought period of 2000-2002 affected 2200000 people in Pakistan (Anjum et al. 2010). In 2003, the development of a strong La Niña phase caused above-normal rainfall during the winter season, minimizing the intensive drought episode (1999-2002). The SPI calculated the number of moderate to severe drought months to be 36 (Baluchistan), 9 (northern areas), 45 (Punjab) and 27 (Sindh), whereas the respective calculations of RDI revealed moderate to severe drought months of 36 (Baluchistan), 9 (northern areas), 36 (Punjab) and 27 (Sindh), summarized in Table 5. It is evident that regional analysis is needed to monitor droughts in terms of their severity and magnitude.

\subsubsection{Twelve month analysis}

This period of drought analysis represents the entire hydrological year (Tigkas et al. 2017). Climate variability and change would play a key role in shaping the water cycle throughout the globe (IPCC 2014). On the 12 mo timeframe, Baluchistan (Fig. 6a) faced moderate droughts in 2000 and severe droughts in 2002, whereas in the northern areas (Fig. 6b), only 1 yr of moderate drought was revealed using RDI calculations. The province of Punjab (Fig. 6c) showed 2 drought years of moderate intensity (1985 and 1987) and 1 drought year of severe intensity (2002) due to a large deficit in monsoon rainfall in July 2002. Sindh province experienced the maximum number of drought years, i.e. 4 years, exhibiting moderate (1991 and 2000) to severe (1987 and 2002) intensity during the analysis period of $37 \mathrm{yr}$ (Fig. 6d). The 12 mo analysis of both indicators depicted the actual number of

Table 5. Calculated number of moderate and severe drought months in provinces of Pakistan. KPK: Khyber Pakhtunkhwa; SPI: standardized precipitation index; RDI: reconnaissance drought index

\begin{tabular}{|c|c|c|c|c|c|c|c|c|c|}
\hline \multirow{2}{*}{ Timescale } & \multirow[t]{2}{*}{ Index } & \multicolumn{2}{|c|}{ Baluchistan } & \multicolumn{2}{|c|}{ KPK } & \multicolumn{2}{|c|}{ Punjab } & \multicolumn{2}{|c|}{ Sindh } \\
\hline & & Moderate & Severe & Moderate & Severe & Moderate & Severe & Moderate & Severe \\
\hline \multirow[t]{2}{*}{$3 \mathrm{mo}$} & SPI & 36 & 3 & 48 & 0 & 39 & 0 & 12 & 0 \\
\hline & RDI & 36 & 3 & 48 & 0 & 36 & 0 & 12 & 0 \\
\hline \multirow[t]{2}{*}{$6 \mathrm{mo}$} & SPI & 6 & 6 & 18 & 0 & 6 & 6 & 18 & 0 \\
\hline & RDI & 6 & 6 & 18 & 0 & 6 & 6 & 18 & 0 \\
\hline \multirow{2}{*}{$9 \mathrm{mo}$} & SPI & 36 & 0 & 0 & 9 & 45 & 0 & 18 & 9 \\
\hline & RDI & 36 & 0 & 0 & 9 & 36 & 0 & 18 & 9 \\
\hline \multirow[t]{2}{*}{$12 \mathrm{mo}$} & SPI & 12 & 12 & 12 & 0 & 12 & 12 & 24 & 24 \\
\hline & RDI & 12 & 12 & 12 & 0 & 24 & 12 & 24 & 24 \\
\hline
\end{tabular}



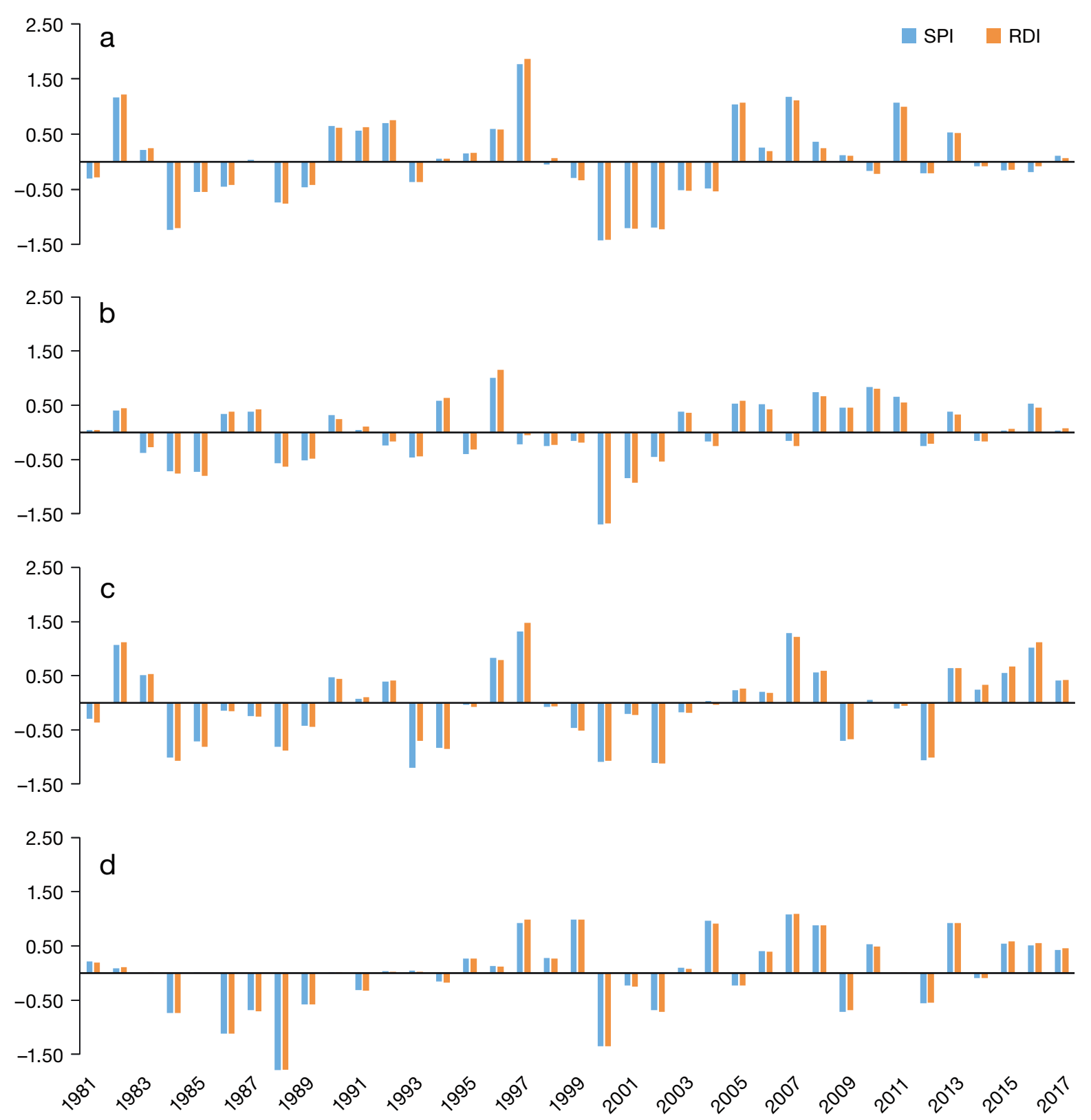

Fig. 5. SPI and RDI time series analysis (1981-2017) for (a) Baluchistan, (b) Khyber Pakhtunkhwa, (c) Punjab and (d) Sindh at 9 mo timescale

moderate to severe drought months (Table 5) in Baluchistan (24 for SPI and 24 for RDI), northern areas (12 for SPI and 12 for RDI), Punjab (24 for SPI and 36 for RDI) and Sindh (48 for SPI and 48 for RDI). The use of SPI and RDI for drought assessment under a changing climate has been well documented in the literature (Al-Faraj et al. 2014, Shokoohi \& Morovati 2015). In summary, on an annual (12 mo) basis, 2002 was the most severe drought period, and both of the indices well captured this period of dryness (Adnan et al. 2018), as they use precipitation and evapotranspira- tion data, which enable them to depict a more realistic picture of droughts in a region of interest (Tigkas et al. 2015, 2017).

\subsection{Drought episode (1999-2002)}

Most of the Asian regions experienced a severe and long-lasting episode of drought from 1999 to 2002 (Malik et al. 2013, Barlow et al. 2016, Rashki et al. 2017). Hence, the analysis of historical drought 


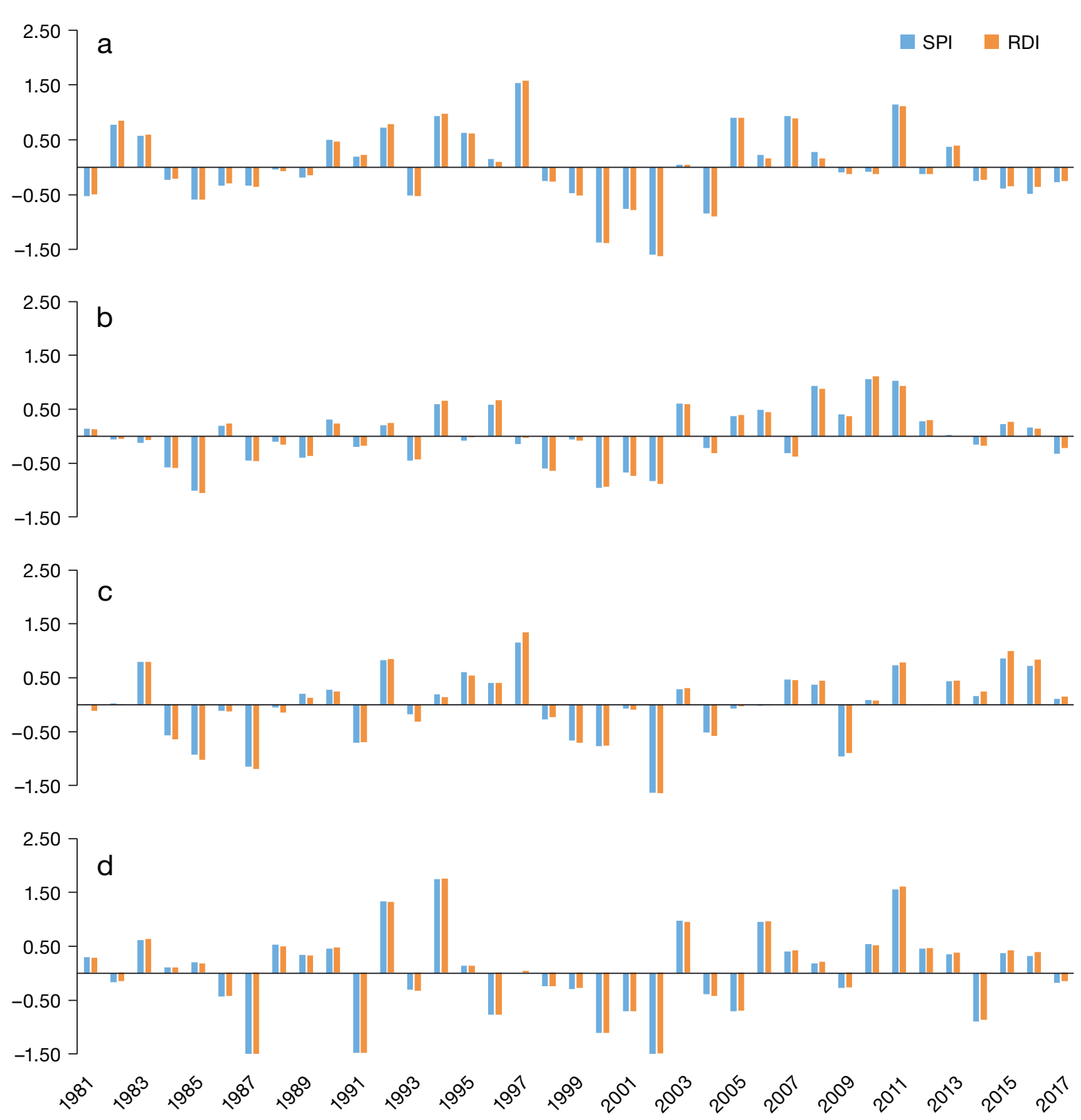

Fig. 6. SPI and RDI time series analysis (1981-2017) for (a) Baluchistan, (b) Khyber Pakhtunkhwa, (c) Punjab and (d) Sindh at a 12 mo timescale

years and their intensity has been investigated and compared with the recent drought-intensive period (1999-2002). All the indices (DI, SPI and RDI) well captured this period, although the magnitude and severity of each index was slightly different (Figs. 7 \& 8). Literature revealed the inception of drought in 1999, but our drought indices slightly captured this period, while the long-term episode of droughts (2000, 2001 and 2002) was well captured by both indices (Fig. 7). The DI also highlighted this period of drought episode (Fig. 8). Annamalai et al. (2013) used the all-India monsoon rainfall (AIMR) index to

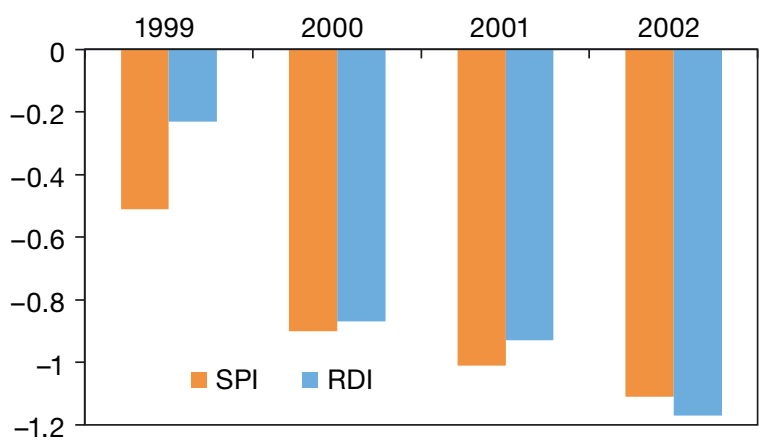

Fig. 7. Recent long-term episode of droughts (1999-2002) across Pakistan 


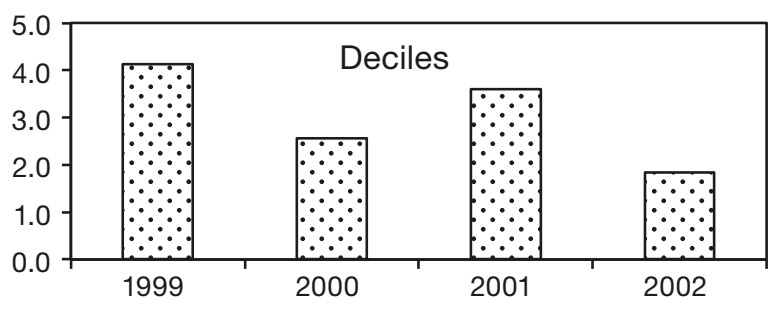

Fig. 8. Descriptive values of deciles index during 1999-2002 across Pakistan

evaluate monsoon rainfall trends over South Asia. Their results showed a decreasing trend of AIMR during the last 5-6 decades (Annamalai et al. 2013). The DI values gradually decreased, ranging from 4.1 in 1999 to 1.8 in 2002 (Fig. 8). This further confirms a decrease in rainfall patterns during 1999-2002.

\section{DISCUSSION}

Assessment of historical drought conditions in different provinces of Pakistan, their implications and links to other studies are further discussed in this section. Recent changes in the intensity and frequency of extreme climate events, particularly droughts, have significantly impacted society (Giddens 2009, Neely et al. 2009). Climate warming is expected to increase the risk of famine in drought-prone areas that are highly dependent on rainfall and water resources (IPCC 2014). It is difficult to predict the length of a drought event (Iglesias et al. 2007, Wilhite 2007, Parry et al. 2016), as rainfall variability defines the trends of drought occurrence, frequency and duration (Hisdal et al. 2001). The wide-ranging impacts of droughts on the environment, economy and society are well documented in the literature (Wilhite et al. 2014, Rey et al. 2016, Parsons et al. 2019).

The per-decade analysis of DI well captured the wet and dry episodes over the country (Table 4), whereas the province-level analysis revealed that Baluchistan and Sindh are highly vulnerable to drought risks due to rainfall departure along the latitudinal belts (Zhang et al. 2012). The level of the water table in both provinces (Baluchistan and Sindh) has declined remarkably due to the overexploitation of groundwater resources (Ahmad et al. 2004), while the economies of developing countries are strongly dependent on rainfed agriculture (Zhang et al. 2007, Telesca et al. 2013, Miyan 2015). The decadal analysis of 1991-1992 to 2000-2001 (Table 4) highlights the long-term drought episode of 1999-2002 (Malik et al. 2013, Adnan et al. 2018), which affected the yield of rainfed crops up to 60$80 \%$ and irrigated crops up to $15-20 \%$ (Sarwar 2008). The overall trend in 4 decades has shifted from dry to humid and wet periods in the region, indicating an increase in annual mean rainfall trends from south to north (Hanif et al. 2013). This increase in rainfall during recent years has also positively influenced the greenery of the northwestern Indian subcontinent, especially the Thar Desert, and the declining trend in dust loading (Zhang et al. 2015, Jin \& Wang 2018). The findings of this study are in good agreement with a study conducted on global precipitation trends (Zhang et al. 2007).

SPI and RDI are well correlated at 3, 6, 9 and 12 mo timescales (Fig. 2), which may be related to regional topology (Adnan et al. 2016). Xie et al.'s (2013) investigations on principal component analysis of SPI fields depicted a clearer picture of widespread droughts in central and southern Pakistan. Overall, the magnitude of RDI with respect to SPI was slightly higher in wet and dry periods, indicating that RDI is an appropriate index to capture drought episodes in the region (Adnan et al. 2018).

The global average temperature over land is expected to increase $\left(1.5^{\circ} \mathrm{C}\right)$ by the end of the $21^{\text {st }}$ century (IPCC 2013). Shifts in weather patterns (including rainfall and temperature) are important to evaluate to predict climate variability (Alexander et al. 2006, Webster et al. 2011). During the examined period (1981-2017), frequent dry spells were investigated in semiarid Pakistan (Table 5), as evidence of a significant warming trend in mean maximum and minimum temperatures (Donat et al. 2013). Occurrence of warm days and nights revealed increasing trends in Hawaii (Safeeq et al. 2013). In the shortterm (3- and 6- mo timescales) analysis, Baluchistan and Punjab experienced the most severe drought episodes, while in the long-term analysis, all provinces in the region experienced severe droughts except KPK. The numbers of moderate to severe drought months are more pronounced in Sindh as compared to other provinces (Table 5).

A westward shift in monsoon rainfall patterns has been reported in the country (Hanif et al. 2013). Interannual rainfall variability indicated a decreasing trend over Kashmir, Pakistan (Kumar \& Jain 2010). This trend further confirms that the southwestern side is more vulnerable to drought risks compared to the northeastern side. This feature of rainfall deficit is of significant importance for southern Baluchistan and the coastal belt of the Indus delta (Adnan et al. 2015). Basit et al. (2012) reported a decreasing rainfall pattern in the country during the summer 
monsoon season; 1998 was a drier year and pointed towards the beginning of a dry weather (drought) period that lasted up to 2000 , followed by a sudden shift in climatic conditions in 2001 that resulted in an uneven monsoon in some parts of the country.

Experts believe that shifting monsoon patterns due to climate warming in South Asia (including Pakistan) would adversely affect ecosystems during the $21^{\text {st }}$ century (Hanif et al. 2013, Barlow et al. 2016). The agriculture sector experienced a severe drought episode during 2000-2001, which significantly affected the growth rate (a decline of $2.6 \%$ ) of crop plants compared to a positive growth rate of $1.4 \%$ during 2001-2002 (Ahmad et al. 2004). However, given the sensitivity of agricultural systems to drought, application of regional predictions within drought monitoring would help minimize the economic losses associated with droughts (Parsons et al. 2019).

Climate variability and change over arid to semiarid and subhumid regions of Pakistan resulted in prolonged droughts (Farhat et al. 2013, Adnan et al. 2018). The period 1997-1998 was marked by a strong ENSO, and this strong ENSO induced a 5 yr drought from 1998 to 2002 in South Asia including Pakistan; this area experienced the most severe drought conditions recorded in the last $50 \mathrm{yr}$, which was revealed by all of the drought indicators used in this study (Figs. 7 \& 8). The possible physical mechanism that strengthened the 1999-2002 drought episode involves the warm ocean water, even though the onset of the cold and wet episode of La Niña had occurred in 1999. This has been defined by different scientists based on a complex coupling mechanism caused by regional and large-scale climatic variability, possibly due to the synergistic effects of an out-of-phase precipitation signal over the study region and the warm pool of western Pacific currents (Barlow et al. 2002, 2016).

In recent decades, the frequent episodes of heat waves and droughts in the country have severely affected socioeconomic conditions (Abbas et al. 2018a,b). Hence, the monitoring of the spatial extent of drought-affected areas and the long-term assessment of the drought-intensive periods are required to highlight the need for water resource management in Pakistan.

\section{CONCLUSIONS}

Droughts are severely affecting the agriculture and water resources of Pakistan. Therefore, a comprehensive study was undertaken (1981-2017) to identify the drought-prone areas in the region. The south- eastern side of the country was found to be more vulnerable to droughts compared to the northwestern side. Climate warming is expected to increase the risk of famine to drought-prone areas that are highly dependent on rainfall. The comparative analysis of SPI and RDI revealed a strong correlation, indicating that both indicators are adequate to capture droughts. The province-level analysis investigated the occurrence of droughts (more pronounced) in Sindh and Baluchistan, whereas some parts of southern Punjab also experienced intense dry spells. The larger spatial extent of the drought-affected areas and the long-term duration of the droughtintensive periods highlight the need for water resource management in Pakistan. This study would help policy makers to adopt measures for drought monitoring and impact assessment in the region.

Acknowledgements. The authors gratefully acknowledge the CAS-TWAS President's PhD Fellowship Program. We thank the Pakistan Meteorological Department for providing the datasets for the study. We are also grateful for the selfless support and guidance of Professor Dr. Riyu Lu.

\section{LITERATURE CITED}

Abbas F, Rehman I, Adrees M, Ibrahim M and others (2018a) Prevailing trends of climatic extremes across Indus-Delta of Sindh-Pakistan. Theor Appl Climatol 131:1101-1117

Abbas F, Sarwar N, Ibrahim M, Adrees M, Ali S, Saleem F, Hammad HM (2018b) Patterns of climate extremes in the coastal and highland regions of Balochistan, Pakistan. Earth Interact 22:1-23

Adnan S, Khan AH (2009) Effective rainfall for irrigated agriculture plains of Pakistan. Pakistan J Meteorol 6: $61-72$

Adnan S, Ullah K, Gao S (2015) Characterization of drought and its assessment over Sindh, Pakistan during 19512010. J Meteorol Res 29:837-857

Adnan S, Ullah K, Shouting G (2016) Investigations into precipitation and drought climatologies in south central Asia with special focus on Pakistan over the period 19512010. J Clim 29:6019-6035

Adnan S, Ullah K, Gao S, Khosa AH, Wang Z (2017) Shifting of agro climatic zones, their drought vulnerability, and precipitation and temperature trends in Pakistan. Int $\mathrm{J}$ Climatol 37:529-543

Adnan S, Ullah K, Shuanglin L, Gao S, Khan AH, Mahmood $\mathrm{R}$ (2018) Comparison of various drought indices to monitor drought status in Pakistan. Clim Dyn 51:1885-1899

Aguilar E, Peterson TC, Obando PR, Frutos R and others (2005) Changes in precipitation and temperature extremes in Central America and northern South America, 1961-2003. J Geophys Res Atmos 110:D23107

Ahmad S, Hussain Z, Qureshi AS, Majeed R, Saleem M (2004) Drought mitigation in Pakistan: current status and options for future strategies. Work Pap No. 85. International Water Management Institute, Colombo

Ahmed K, Shahid S, bin Harun S, Wang XJ (2016) Charac- 
terization of seasonal droughts in Balochistan Province, Pakistan. Stochastic Environ Res Risk Assess 30:747-762 Ahmed K, Shahid S, Ismail T, Nawaz N, Wang XJ (2018a) Absolute homogeneity assessment of precipitation time series in an arid region of Pakistan. Atmosfera 31: 301-316

Ahmed K, Shahid S, Nawaz N (2018b) Impacts of climate variability and change on seasonal drought characteristics of Pakistan. Atmos Res 214:364-374

Al-Faraj FAM, Scholz M, Tigkas D (2014) Sensitivity of surface runoff to drought and climate change: application for shared river basins. Water 6:3033-3048

Alexander LV, Zhang X, Peterson TC, Caesar J and others (2006) Global observed changes in daily climate extremes of temperature and precipitation. J Geophys Res Atmos 111:D05109

Anjum SA, Wang L, Salhab J, Khan I, Saleem M (2010) An assessment of drought extent and impacts in agriculture sector in Pakistan. J Food Agric Environ 8:1359-1363

Anjum S, Saleem MF, Cheema M, Bilal MF, Khaliq T (2012) An assessment to vulnerability, extent, characteristics and severity of drought hazard in Pakistan. Pak J Sci 64: 138

Annamalai H, Hafner J, Sooraj KP, Pillai P (2013) Global warming shifts the monsoon circulation, drying South Asia. J Clim 26:2701-2718

Barlow M, Cullen H, Lyon B (2002) Drought in central and southwest Asia: La Niña, the warm pool, and Indian Ocean precipitation. J Clim 15:697-700

Barlow M, Zaitchik B, Paz S, Black E, Evans J, Hoell A (2016) A review of drought in the Middle East and southwest Asia. J Clim 29:8547-8574

Basit A, Raza SS, Irfan N, Avila R (2012) Simulation of monsoon precipitation over South-Asia using RegCM3. ISRN Meteorol 2012:754902

Donat MG, Alexander LV, Yang H, Durre I and others (2013) Updated analyses of temperature and precipitation extreme indices since the beginning of the twentieth century: the HadEX2 dataset. J Geophys Res Atmos 118: 2098-2118

Du J, Fang J, Xu W, Shi P (2013) Analysis of dry/wet conditions using the standardized precipitation index and its potential usefulness for drought/flood monitoring in Hunan Province, China. Stochastic Environ Res Risk Assess 27:377-387

Duffy PB, Brando P, Asner GP, Field CB (2015) Projections of future meteorological drought and wet periods in the Amazon. Proc Natl Acad Sci USA 112:13172-13177

Edwards DC (1997) Characteristics of 20th century drought in the United States at multiple time scales. MSc thesis, Colorado State University, Fort Collins, CO

Farhat A, Ahmad A, Safeeq M, Ali S, Saleem F, Hammad HM, Farhad W (2013) Changes in precipitation extremes over arid to semiarid and subhumid Punjab. Theor Appl Climatol 116:671-680

Gibbs WJ, Maher JV (1967) Rainfall deciles as drought indicators. Bull No. 48. Bureau of Meteorology, Melbourne

Giddens A (2009) Politics of climate change. Polity Press, Cambridge

Gilbert RO (1987) Statistical methods for environmental pollution monitoring. John Wiley \& Sons, New York, NY

Gocic M, Trajkovic S (2014) Drought characterisation based on water surplus variability index. Water Resour Manage 28:3179-3191

Guha-Sapir D, Vos F, Below R, Ponserre S (2012) Annual dis- aster statistical review 2011: the numbers and trends. Centre for Research on the Epidemiology of Disasters, Brussels

*Haied N, Foufou A, Chaab S, Azlaoui M, Khadri S, Benzahia $\mathrm{K}$, Benzahia I (2017) Drought assessment and monitoring using meteorological indices in a semi-arid region. Energy Procedia 119:518-529

* Hanif M, Khan AH, Adnan S (2013) Latitudinal precipitation characteristics and trends in Pakistan. J Hydrol (Amst) 492:266-272

KHaroon MA, Zhang J, Yao F (2016) Drought monitoring and performance evaluation of MODIS-based drought severity index (DSI) over Pakistan. Nat Hazards 84:1349-1366

*Hayes M, Svoboda M, Wall N, Widhalm M (2011) The Lincoln declaration on drought indices: universal meteorological drought index recommended. Bull Am Meteorol Soc 92:485-488

*Hisdal H, Stahl K, Tallaksen LM, Demuth S (2001) Have streamflow droughts in Europe become more severe or frequent? Int J Climatol 21:317-333

Huang R, Yan D, Liu S (2015) Combined characteristics of drought on multiple time scales in Huang-Huai-Hai River basin. Arab J Geosci 8:4517-4526

*Hui-Mean F, Yusop Z, Yusof F (2018) Drought analysis and water resource availability using standardised precipitation evapotranspiration index. Atmos Res 201:102-115

*Hunt KMR, Turner AG, Shaffrey LC (2018) The evolution, seasonality and impacts of western disturbances. QJR Meteorol Soc 144:278-290

* Iglesias A, Garrote L, Flores F, Moneo M (2007) Challenges to manage the risk of water scarcity and climate change in the Mediterranean. Water Resour Manage 21:775-788

IPCC (2013) Climate change 2013: the physical science basis. In: Stocker TF, Qin D, Plattner GK, Tignor M and others (eds) Contribution of Working Group I to the 5th Assessment Report of the Intergovernmental Panel on Climate Change. Cambridge University Press, Cambridge

IPCC (2014) Climate change 2014: synthesis report. In: Core Writing Team, Pachauri RK, Meyer L (eds) Contribution of Working Groups I, II and III to the Fifth Assessment Report of the Intergovernmental Panel on Climate Change. IPCC, Geneva

Jin Q, Wang C (2018) The greening of northwest Indian subcontinent and reduction of dust abundance resulting from Indian summer monsoon revival. Sci Rep 8:4573

KKaniewski D, Van Campo E, Weiss H (2012) Drought is a recurring challenge in the Middle East. Proc Natl Acad Sci USA 109:3862-3867

Kaskaoutis DG, Gautam R, Singh RP, Houssos EE and others (2012) Influence of anomalous dry conditions on aerosols over India: transport, distribution and properties. J Geophys Res Atmos 117:D09106

Kazmi DH, Li J, Rasul G, Tong J and others (2015) Statistical downscaling and future scenario generation of temperatures for Pakistan region. Theor Appl Climatol 120: 341-350

Kendall M (1948) Rank correlation methods. Griffin, Oxford * Kim DW, Byun HR, Choi KS, Oh SB (2011) A spatiotemporal analysis of historical droughts in Korea. J Appl Meteorol Climatol 50:1895-1912

Kumar V, Jain SK (2010) Trends in seasonal and annual rainfall and rainy days in Kashmir Valley in the last century. Quat Int 212:64-69

Li Q, Li P, Li H, Yu M (2015) Drought assessment using a 
multivariate drought index in the Luanhe River basin of northern China. Stochastic Environ Res Risk Assess 29: 1509-1520

Malik KM, Taylor PA, Szeto K, Khan AH (2013) Characteristics of central southwest Asian water budgets and their impacts on regional climate. Atmos Clim Sci 3:259

Mann HB (1945) Nonparametric tests against trend. Econometrica 13:245-259

McKee TB, Doesken NJ, Kleist J (1993) The relationship of drought frequency and duration to time scales. Proc 8th Conf Appl Climatol 1993:179-184

McKee TB, Doesken NJ, Kleist J (1995) Drought monitoring with multiple time scales. Proc 9th Conf Appl Climatol 1995:233-236

Mendicino G, Senatore A, Versace P (2008) A groundwater resource index (GRI) for drought monitoring and forecasting in a Mediterranean climate. J Hydrol (Amst) 357: 282-302

Mishra AK, Singh VP (2010) A review of drought concepts. J Hydrol (Amst) 391:202-216

Miyan MA (2015) Droughts in Asian least developed countries: vulnerability and sustainability. Weather Clim Extrem 7:8-23

Mondal A, Kundu S, Mukhopadhyay A (2012) Rainfall trend analysis by Mann-Kendall test: a case study of northeastern part of Cuttack district, Orissa. Int J Geol Earth Environ Sci 2:70-78

Mondol MAH, Das SC, Islam MN (2016) Application of standardized precipitation index to assess meteorological drought in Bangladesh. Jàmbá 8:280

Morid S, Smakhtin V, Moghaddasi M (2006) Comparison of seven meteorological indices for drought monitoring in Iran. Int J Climatol 26:971-985

Nam WH, Hayes MJ, Svoboda MD, Tadesse T, Wilhite DA (2015) Drought hazard assessment in the context of climate change for South Korea. Agric Water Manage 160: 106-117

Neely C, Bunning S, Wilkes A (eds) (2009) Review of evidence on drylands pastoral systems and climate change: implications and opportunities for mitigation and adaptation. Land Water Discuss Pap 8. FAO, Rome

Oki T, Kanae S (2006) Global hydrological cycles and world water resources. Science 313:1068-1072

* Palmer WC (1968) Keeping track of crop moisture conditions, nationwide: the new crop moisture index. Weatherwise 21:156-161

* Parry S, Wilby RL, Prudhomme C, Wood PJ (2016) A systematic assessment of drought termination in the United Kingdom. Hydrol Earth Syst Sci 20:4265-4281

* Parsons DJ, Rey D, Tanguy M, Holman IP (2019) Regional variations in the link between drought indices and reported agricultural impacts of drought. Agric Syst 173: 119-129

Rashki A, Kaskaoutis DG, Rautenbach CJdeW, Eriksson PG, Qiang M, Gupta P (2012) Dust storms and their horizontal dust loading in the Sistan region, Iran. Aeolian Res 5: 51-62

Rashki A, Rautenbach CJdeW, Eriksson PG, Kaskaoutis DG, Gupta P (2013a) Temporal changes of particulate concentration in the ambient air over the city of Zahedan, Iran. Air Qual Atmos Health 6:123-135

Rashki A, Eriksson PG, Rautenbach CJdeW, Kaskaoutis DG, Grote W, Dykstra J (2013b) Assessment of chemical and mineralogical characteristics of airborne dust in the Sistan region, Iran. Chemosphere 90:227-236
Rashki A, Kaskaoutis DG, Goudie AS, Kahn RA (2013c) Dryness of ephemeral lakes and consequences for dust activity: the case of the Hamoun drainage basin, southeastern Iran. Sci Total Environ 463-464:552-564

Rashki A, Kaskaoutis DG, Francois P, Kosmopoulos PG, Legrand M (2015) Dust-storm dynamics over Sistan region, Iran: seasonality, transport characteristics and affected areas. Aeolian Res 16:35-48

Rashki A, Arjmand M, Kaskaoutis DG (2017) Assessment of dust activity and dust-plume pathways over Jazmurian Basin, southeast Iran. Aeolian Res 24:145-160

* Rey D, Holman IP, Daccache A, Morris J, Weatherhead EK, Knox JW (2016) Modelling and mapping the economic value of supplemental irrigation in a humid climate. Agric Water Manage 173:13-22

* Safeeq M, Mair A, Fares A (2013) Temporal and spatial trends in air temperature on the island of Oahu, Hawaii. Int J Climatol 33:2816-2835

Salma S, Shah M, Rehman S (2012) Rainfall trends in different climate zones of Pakistan. Pakistan J Meteorol 9: 37-47

Salmi T, Määttä A, Anttila P, Ruoho-Airola T, Amnell T (2002) Detecting trends of annual values of atmospheric pollutants by the Mann-Kendall test and Sen's slope estimates - the Excel template application MAKESENS. Publ Air Qual No. 31. Finnish Meteorological Institute, Helsinki

* Samaniego L, Kumar R, Zink M (2013) Implications of parameter uncertainty on soil moisture drought analysis in Germany. J Hydrometeorol 14:47-68

Sarwar A (2008) Droughts in Pakistan-a socio-political perspective. In: Jairath J, Ballabh V (eds) Droughts and integrated water resource management in South Asia: issues, alternatives and futures. SAGE Publications, New Delhi, p 200-230

* Sen PK (1968) Estimates of the regression coefficient based on Kendall's tau. J Am Stat Assoc 63:1379-1389

Shokoohi A, Morovati R (2015) Basinwide comparison of RDI and SPI within an IWRM framework. Water Resour Manage 29:2011-2026

Soro GE, Anouman DGL, Goula Bi TA, Srohorou B, Savane I (2014) Caractérisation des séquences de sècheresse météorologique à diverses échelles de temps en climat de type soudanais: cas de l'extrême nord-ouest de la Cote d'Ivoire. LARHYSS J 18:107-124

Svoboda M, Hayes M, Wood DA (2012) Standardized precipitation index user guide. World Meteorological Organization, Geneva

* Tabari H, Abghari H, Hosseinzadeh Talaee P (2012) Temporal trends and spatial characteristics of drought and rainfall in arid and semiarid regions of Iran. Hydrol Processes 26:3351-3361

* Telesca L, Vicente-Serrano SM, López-Moreno JI (2013) Power spectral characteristics of drought indices in the Ebro River basin at different temporal scales. Stochastic Environ Res Risk Assess 27:1155-1170

* Thomas T, Jaiswal RK, Galkate RV, Nayak TR (2016) Reconnaissance drought index based evaluation of meteorological drought characteristics in Bundelkhand. Procedia Technol 24:23-30

* Thornthwaite CW (1948) An approach toward a rational classification of climate. Geogr Rev 38:55-94

Tigkas D (2008) Drought characterisation and monitoring in regions of Greece. Eur Water 23:29-39

Tigkas D, Vangelis H, Tsakiris G (2013) The RDI as a composite climatic index. Eur Water 41:17-22 
Tigkas D, Vangelis H, Tsakiris G (2015) DrinC: a software for drought analysis based on drought indices. Earth Sci Inform 8:697-709

Tigkas D, Vangelis H, Tsakiris G (2017) An enhanced effective reconnaissance drought index for the characterisation of agricultural drought. Environ Process 4:137-148

Touma D, Ashfaq M, Nayak MA, Kao SC, Diffenbaugh NS (2015) A multi-model and multi-index evaluation of drought characteristics in the 21st century. J Hydrol (Amst) 526:196-207

Trnka M, Balek J, Št pánek P, Zahradní ek P and others (2016) Drought trends over part of central Europe between 1961 and 2014. Clim Res 70:143-160

Tsakiris G, Vangelis H (2005) Establishing a drought index incorporating evapotranspiration. Eur Water 9:3-11

Tsakiris G, Pangalou D, Vangelis H (2007) Regional drought assessment based on the reconnaissance drought index (RDI). Water Resour Manage 21:821-833

Vangelis H, Tigkas D, Tsakiris G (2013) The effect of PET method on reconnaissance drought index (RDI) calculation. J Arid Environ 88:130-140

Webster P, Toma VE, Kim HM (2011) Were the 2010 Pakistan floods predictable? Geophys Res Lett 38:L04806

Wilhite DA (2007) Preparedness and coping strategies for agricultural drought risk management: recent progress and trends. In: Sivakumar MVK, Motha RP (eds) Managing weather and climate risks in agriculture. Springer, Berlin

Wilhite DA, Sivakumar MVK, Pulwarty R (2014) Managing

Editorial responsibility: Eduardo Zorita, Geesthacht, Germany drought risk in a changing climate: the role of national drought policy. Weather Clim Extrem 3:4-13

* Wu H, Hayes MJ, Weiss A, Hu Q (2001) An evaluation of the standardized precipitation index, the China Z index and the statistical Z score. Int J Climatol 21:745-758

Xie H, Ringler C, Zhu T, Waqas A (2013) Droughts in Pakistan: a spatiotemporal variability analysis using the standardized precipitation index. Water Int 38:620-631

Karch MAA, Malekinezhad H, Mobin MH, Dastorani MT, Kousari MR (2011) Drought monitoring by reconnaissance drought index (RDI) in Iran. Water Resour Manage 25:3485

Z Zhang X, Zwiers FW, Hegerl GC, Lambert FH and others (2007) Detection of human influence on twentieth-century precipitation trends. Nature 448:461

Zhang Q, Xu CY, Tao H, Jiang T, Chen YD (2010) Climate changes and their impacts on water resources in the arid regions: a case study of the Tarim River basin, China. Stochastic Environ Res Risk Assess 24:349-358

* Zhang Q, Li J, Singh VP, Bai Y (2012) SPI-based evaluation of drought events in Xinjiang, China. Nat Hazards 64: 481-492

Khang A, Zheng C, Wang S, Yao Y (2015) Analysis of streamflow variations in the Heihe River basin, northwest China: trends, abrupt changes, driving factors and ecological influences. J Hydrol Reg Stud 3:106-124

* Zhao T, Dai A (2015) The magnitude and causes of global drought changes in the twenty-first century under a low-moderate emissions scenario. J Clim 28:4490-4512

Submitted: April 2, 2019; Accepted: July 1, 2019 Proofs received from author(s): August 10, 2019 